\title{
SUBSTITUSI TEPUNG DAUN MENGKUDU DALAM RANSUM MENINGKATKAN KINERJA AYAM BROILER
}

\author{
Tuty Maria Wardiny (tuty@ut.ac.id) \\ T. Eduard Azwar Sinar \\ PS Agribisnis, Fakultas Biologi, Universitas Terbuka, Ciputat, Tangerang 15418 \\ Desmayati Zainuddin \\ Balai Penelitian Ternak, PO Box 221, Bogor 16002
}

\begin{abstract}
An experiment was conduted to evaluate the effectiveness level of corn substituted by Morinda citrifolia leaf meal in broiler ration. The use of Morinda citrifolia leaf meal substituted for corn in ration is expected to improve feed conversion in broiler chickens and produce chicken meat that safe for consumption and free of chemical antibiotics residues . Completely Randomized Design (CRD) was used to analyze data obtained from this research. One hundred and sixty chicleas (7 days aged) divided into 5 (five) treatments with 4 (four) replications and each replication consisted of 8 (eight) chicleas. Ration of treatments were a negative control diet (R0), 1\% Morinda citrifolia leaf meal (R1), 2\% Morinda citrifolia leaf meal (R2), 3\% Morinda citrifolia leaf meal (R3) and commersial ration (R4). All treatments rations were added a natural feed additive that consist of 0,125\% Curcuma and.0,075\% Turmeric meal. Measured parameters were feed intake, weight gain, feed conversion ratio, mortality, percentages of carcas and abdominal fat. Results showed that feed consumption, weight gain, and feed conversion ratio were significantly $(p<0.05)$ influenced by treatments. Mortality, percentage of carcas and abdominal fat were not significantly $(p>0.05)$ influenced by ration treatments. Mortality rates in chickens using a ration of treatment was $0 \%$, while using the control diet 0,78\% (1 bird). The counclusion showed that the substitution of 1-2\% Morinda citrifolia leaf meal in ration has better performance compared to the control diet, with improvement of feed conversion ratio was 7.57 and $9.2 \%$ respectively was more efficient than the control diets.
\end{abstract}

Key words: broiler chicken, feed additives, morinda citrifolia leaf meal

Pakan merupakan aspek penting dalam usaha ternak selain bibit, di samping itu pakan dari segi finansial juga merupakan faktor yang memiliki peranan paling besar dalam hal biaya produksi, dibandingkan dengan faktor-faktor lainnya. Karena itu penerapan program pakan yang tidak sesuai akan mengakibatkan pembengkakan biaya produksi dan dapat memperkecil profit values yang diperoleh. Dari seluruh total pakan nasional yang ada, sekitar 83\% digunakan untuk peternakan unggas (Widodo, 2010). Penggunaan pakan pada produksi unggas mencapai sekitar $60-70 \%$ dari total biaya produksi. Kebutuhan pakan terus meningkat seiring dengan peningkatan permintaan terhadap produk-produk peternakan, khususnya komoditas unggas yaitu daging ayam dan telur 
sebagai akibat adanya pertambahan penduduk, peningkatan pendapatan serta kesadaran akan gizi seimbang.

Komponen pakan sampai saat ini masih banyak bergantung pada produk impor, terutama sumber protein (kedelai, tepung ikan dan meal bone) serta jagung. Kalangan pengusaha pakan ternak memperkirakan kebutuhan jagung dari tahun ke tahun akan meningkat. Bahkan kebutuhan akan komoditas tersebut pada tahun 2010 diperkirakan mencapai jutaan ton. Jika tidak ada peningkatan produksi jagung domestik secara signifikan, ketergantungan bahan pakan terhadap impor jagung secara langsung akan memukul industri pakan ternak nasional karena harga jagung impor akan mengikuti dinamika harga pasar international (Widodo, 2010).

Sebagai upaya menekan biaya pakan yang tinggi, diperlukan adanya usaha-usaha yang efisien dalam pemanfaatan ransum untuk ternak, supaya peningkatan pendapatan dapat dicapai sesuai yang diharapkan. Salah satu upaya yang dapat dilakukan untuk memperbaiki efisiensi pakan adalah substitusi jagung dengan bahan pakan yang tidak bersaing dengan kebutuhan manusia; tetapi memiliki nilai nutrisi yang tinggi dan tidak menimbulkan bahaya bagi ternak yang memakannya maupun manusia yang mengkonsumsi produk hasil peternakan tersebut. Salah satu bahan yang dapat digunakan sebagai substitusi jagung dalam ransum broiler adalah tepung daun mengkudu (Morinda citrifolia).

Tanaman mengkudu (Morinda citrifolia L) merupakan salah satu tanaman obat yang sudah dimanfaatkan sejak jaman purba hampir diseluruh belahan dunia. Pada 100 tahun Sebelum Masehi (SM), penduduk Asia Tenggara telah memanfaatkan tanaman mengkudu sebagai obat (Waha, 2001). Pada daun mengkudu terkandung protein, zat kapur, zat besi, karoten dan askorbin. Efek farmakologis daun mengkudu pertama kali ditemukan oleh Raj dalam Darusman (2002) yang melaporkan bahwa ekstrak kloroform daun muda mengkudu secara in vitro mempunyai aktivitas anthielmintik, cukup baik melawan cacing Ascaris lumbricoides yang ada pada usus. Aalbersberg dkk (1993) melaporkan bahwa kandungan karotin pada daun mengkudu lebih tinggi dibandingkan dengan yang terkandung pada Brassica chinensis dan Colocasia esculenta. Penelitian Apriyantono dan Farid (2002) melaporkan bahwa daun dan akar mengkudu mengandung senyawa antrakuinon (damnakantal) yang berfungsi sebagai antiseptik, antibakteri, dan antikanker. Daun mengkudu juga mengandung xeronine yang dikenal dapat membantu penyerapan protein (Bangun dan Sarwono, 2002).

Berdasarkan hasil penelitian Wardiny (2006) tepung daun mengkudu mengandung protein kasar 22,11\%, Ca 10,30\%, Fe 437 ppm, Zn 35,80 ppm dan $\beta$-karoten 161 ppm. Berdasarkan data tersebut dapat dilihat bahwa kandungan protein tepung daun mengkudu jauh lebih tinggi jika dibandingkan jagung dan penggunaannya tidak bersaing dengan kebutuhan manusia. Pemberian $9 \%$ tepung daun mengkudu dalam ransum ayam ras petelur memberikan produksi telur ( $77,91 \%)$ yang tinggi serta konversi ransum 2,33 dan kandungan kolesterol yang rendah (8,93 mg/g).

Penelitian ini dilakukan untuk mengevaluasi daya substitusi tepung daun mengkudu terhadap jagung dalam ransum ayam broiler. Pemanfaatan tepung daun mengkudu sebagai pengganti jagung dalam pakan diharapkan dapat memperbaiki produktifitas dan menurunkan tingkat mortalitas ayam broiler.

\section{METODE PENELITIAN}


Seratus enam puluh ekor ayam broiler umur 7 hari dibagi dalam 16 petak kandang litter, masing-masing 8 ekor. Lima perlakuan ransum diberi suplementasi tepung daun mengkudu sebanyak 0, 1, 2 dan 3\% dan ransum komersial, tiap perlakuan terdiri atas 4 ulangan. Ransum disusun isoprotein (21\%) dan isokalori (3000 kkal ME/kg), methionin 0,49\%, lisin 1,35\%, Ca 1,01\% dan $\mathrm{P}$ tersedia $0,36 \%$. Semua ransum perlakuan tepung daun mengkudu, tanpa diberi imbuhan antibiotik konvensional, tetapi diberi imbuhan antibiotik alami yaitu 0,125\% serbuk temulawak (Curcuma xanthorrhiza Roxb) dan 0,075\% serbuk kunyit (Curcuma domestica) .

Tepung daun mengkudu yang digunakan dalam penelitian ini berasal dari daerah Kabupaten Bogor. Penyediaan tepung daun mengkudu dilakukan dengan cara daun mengkudu segar dicuci, kemudian dipotong dan dikeringkan dalam oven $60^{\circ} \mathrm{C}$ sampai kering, digiling dan dicampurkan ke dalam ransum masing-masing $(0,1,2$ dan 3\% ransum). Ransum dan air minum diberikan secara tidak terbatas mulai dari umur 1 hingga 30 hari. Pada umur 4 dan 21 hari anak ayam diberi vaksin ND, sedangkan vaksin gumboro diberikan pada umur 10 hari.

Selama penelitian berlangsung dilakukan pengamatan terhadap bobot hidup, konsumsi ransum, konversi ransum, mortalitas, persentase karkas dan persentase lemak abdominal. Data yang diperoleh dianalisis dengan sidik ragam pola rancangan acak lengkap bila analisis sidik ragam nyata pada $P<0,05$ dilanjutkan dengan uji Duncan (Steel \& Torrie,1993).

\section{HASIL DAN PEMBAHASAN}

Dalam penelitian ini, aspek yang akan dibahas adalah konsumsi ransum, pertumbuhan bobot badan, konversi ransum, mortalitas dan persentase karkas.

\section{Konsumsi Ransum}

Konsumsi ransum menunjukkan hasil yang tidak berbeda nyata $(P>0,05)$ bila dibandingkan dengan ransum kontrol, tetapi berbeda nyata $(P<0,05)$ dibandingkan dengan ransum komersil. Konsumsi ransum ayam yang mendapat tepung daun mengkudu cenderung lebih rendah dibandingkan dengan kontrol dan ransum komersil (Tabel 1).

Tabel 1. Pengaruh Substitusi Tepung Daun Mengkudu (TDM) terhadap Konsumsi Ransum Ayam Broiler

\begin{tabular}{lc}
\hline Perlakuan & Konsumsi Ransum (g/ekor) \\
\hline R0 & $2796,34^{\mathrm{a}} \pm 55,31$ \\
R1 & $2778,94^{\mathrm{a}} \pm 75,48$ \\
R2 & $2733,94^{\mathrm{a}} \pm 57,91$ \\
R3 & $2759,36^{\mathrm{a}} \pm 104,75$ \\
R4 & $3079,11^{\mathrm{b}} \pm 43,38$ \\
\hline
\end{tabular}

Keterangan: rataan dengan superskrip yang berbeda dalam satu kolom menunjukkan perbedaan nyata $(\mathrm{P}<0,05) ; \mathrm{R0}=$ ransum kontrol $(0 \%$ TDM), $\mathrm{R} 1$ = ransum dengan $1 \% \mathrm{TDM}$, $\mathrm{R} 2=$ ransum dengan $2 \% \mathrm{TDM}, \mathrm{R} 3=$ ransum dengan $3 \% \mathrm{TDM}$ dan $\mathrm{R} 4=$ ransum komersil 
Konsumsi ransum tidak menunjukkan hasil yang berbeda nyata bila dibandingkan dengan ransum kontrol, tetapi nyata menurun jika dibandingkan dengan ransum komersil. Hasil ini sesuai dengan penelitian Wardiny (2006) yang melaporkan bahwa pemberian tepung daun mengkudu sebesar 3\%-9\% dalam ransum ayam petelur tidak memberikan pengaruh yang nyata terhadap konsumsi ransum. Tetapi Sangadji, et al. (2005) melaporkan bahwa pemberian tepung daun mengkudu sebesar 15\% dalam ransum yang berbentuk crumble dapat meningkatkan konsumsi ransum ayam broiler, sedangkan Bestari, dkk. (2005) menyatakan bahwa pemberian tepung daun mengkudu yang direndam dalam air panas sebesar 5-15\% dalam ransum, nyata menurunkan konsumsi ransum ayam broiler. Jadi perlakuan terhadap daun mengkudu, level yang diberikan dan bentuk dari ransum sangat mempengaruhi konsumsi ransum ayam. Hhasil penelitian ini menyatakan bahwa substitusi tepung daun mengkudu sampai dengan level 3\% masih dapat ditolerir oleh ayam broiler, karena ransum yang dikonsumsinya tidak berbeda nyata dengan ransum kontrol. Berarti tepung daun mengkudu sampai dengan level 3\% aman digunakan untuk mensubstitusi jagung dalam ransum ayam broiler.

\section{Pertambahan Bobot Badan}

Pertambahan bobot badan ayam selama penelitian nyata $(P<0,05)$ dipengaruhi oleh perlakuan (Tabel 2). Peningkatan level Tepung Daun Mengkudu (TDM) dalam ransum diikuti peningkatan pertambahan bobot badan, tetapi masih rendah jika dibandingkan dengan ransum komersil. Pertambahan bobot badan nyata lebih rendah jika dibandingkan dengan ransum komersil, tetapi pemberian tepung daun mengkudu level rendah sampai sedang (1 dan 2\%) nyata lebih tinggi dibandingkan dengan ransum kontrol, yaitu naiknya level tepung daun mengkudu diikuti naiknya pertambahan bobot badan sampai dengan level sedang (2\% ransum). Pertambahan bobot badan ayam yang mendapat tepung daun mengkudu level tertinggi sama dengan kontrol, sedangkan yang mendapat level lebih rendah dan sedang (1 dan $2 \%$ ransum) cenderung lebih tinggi.

Tabel 2. Pengaruh Substitusi Tepung Daun Mengkudu (TDM) terhadap Pertambahan Bobot Badan Ayam Broiler

\begin{tabular}{cl}
\hline Perlakuan & Pertambahan Bobot Badan (g/ekor) \\
\hline R0 & $1516,02^{\mathrm{a}} \pm 52,17$ \\
R1 & $1626,68^{\mathrm{b}} \pm 31,78$ \\
R2 & $1627,52^{\mathrm{b}} \pm 32,89$ \\
R3 & $1565,02^{\mathrm{ab}} \pm 15,49$ \\
R4 & $1769,69^{\mathrm{c}} \pm 57,87$ \\
\hline
\end{tabular}

Keterangan: rataan dengan superskrip yang berbeda dalam satu kolom menunjukkan perbedaan nyata $(\mathrm{P}<0,05) ; \mathrm{R0}=$ ransum kontrol $(0 \%$ TDM $), \mathrm{R} 1=$ ransum dengan $1 \% \mathrm{TDM}$, $\mathrm{R} 2=$ ransum dengan $2 \% \mathrm{TDM}, \mathrm{R} 3=$ ransum dengan $3 \% \mathrm{TDM}$ dan $\mathrm{R} 4=$ ransum komersil 
Berbagai penelitian tentang buah mengkudu sudah banyak dilakukan, akan tetapi pengkajian dan pemanfaatan tepung daun mengkudu sebagai pengganti jagung dalam ransum ayam broiler belum banyak dilaporkan. Wardiny (2006) melaporkan tepung daun mengkudu mengandung $\beta$-karoten, Fe, dan Zn, dapat membuat ayam lebih cepat dewasa kelamin, produksi telur meningkat dan konversi ransum menurun. Pertambahan bobot badan menunjukkan hasil yang berbeda nyata, pertambahan bobot badan tertinggi terdapat pada ayam yang mendapat ransum komersil, sedangkan pada tepung daun mengkudu ditemukan pada level sedang. Kandungan $\beta$-karoten, Fe, dan Zn yang terdapat pada daun mengkudu membuat ayam cepat pertumbuhannya. Hal ini sesuai dengan Piliang (2004) yang menyatakan bahwa fungsi vitamin A untuk penglihatan dan berperan dalam pertumbuhan serta reproduksi. Mineral Zn penting untuk berfungsinya enzim Pancreatic carboxypeptidase $A$ dan $B$ yang mencerna peptida-peptida menjadi asam-asam amino, enzim Dipeptidase yang memecah dipeptida menjadi bentuk asam-asam amino bebas dan enzim Protease yang memecah protein dalam pencernaan agar dapat diabsorpsi. Adanya peningkatan daya cerna ini mengakibatkan asupan zat-zat makanan menjadi lebih baik sehingga pertambahan bobot badan yang dihasilkan lebih tinggi. Selain itu kandungan xeronine yang terdapat pada daun mengkudu, dikenal dapat membantu penyerapan protein (Bangun \& Sarwono, 2002).

\section{Konversi Ransum}

Konversi ransum menunjukkan hasil yang berbeda nyata $(P<0,05)$, bila dibandingkan dengan ransum kontrol dan komersil sampai dengan substitusi tepung daun mengkudu $2 \%$ (Tabel 3). Konversi ransum yang mendapat tepung daun mengkudu level 1 dan $2 \%$ ransum, nyata $(P<0,05)$ lebih rendah atau lebih efisien dibandingkan dengan kontrol, sementara kontrol, ransum komersil dan tepung daun mengkudu level 3\% dalam ransum tidak berbeda nyata.

Tabel 3. Pengaruh Substitusi Tepung Daun Mengkudu (TDM) terhadap Konversi Ransum Ayam Broiler

\begin{tabular}{cc}
\hline Perlakuan & Konversi Ransum \\
\hline R0 & $1,85^{\mathrm{b}} \pm 0,10$ \\
R1 & $1,71^{\mathrm{a}} \pm 0,07$ \\
R2 & $1,68^{\mathrm{a}} \pm 0,05$ \\
R3 & $1,77^{\mathrm{ab}} \pm 0,61$ \\
R4 & $1,74^{\mathrm{ab}} \pm 0,06$
\end{tabular}

Keterangan: rataan dengan superskrip yang berbeda dalam satu kolom menunjukkan perbedaan nyata $(P<0,05) ; R 0=$ ransum kontrol $(0 \%$ TDM $), R 1=$ ransum dengan $1 \%$ TDM, $\mathrm{R} 2=$ ransum dengan $2 \% \mathrm{TDM}, \mathrm{R} 3=$ ransum dengan $3 \% \mathrm{TDM}$ dan $\mathrm{R} 4=$ ransum komersil

Konversi ransum menggambarkan berapa ransum yang dikonsumsi untuk setiap kg pertambahan bobot badan. Konversi ransum adalah salah satu tolak ukur untuk mengetahui apakah ransum yang diberikan pada ayam telah memenuhi syarat atau belum. Semakin tinggi nilai konversi 
ransum, berarti ransum tersebut semakin buruk kualitas nilai gizinya. Jumlah konsumsi ransum yang sama pada tingkat pertambahan bobot badan yang semakin besar akan menghasilkan nilai konversi ransum yang semakin kecil. Terjadinya perbedaan konversi ransum pada penelitian ini, dapat dijelaskan sebagai berikut: konsumsi ransum tidak dipengaruhi oleh ransum perlakuan, tetapi bila dikaitkan dengan pertambahan bobot badan (Tabel 1) terlihat dengan jelas bahwa substitusi tepung daun mengkudu sampai dengan level $2 \%$ dalam ransum dapat memberikan pertambahan bobot badan yang tinggi. Dengan demikian maka konversi ransum semakin kecil nilainya. Selain itu dapat juga disebabkan oleh adanya kandungan saponin dalam daun mengkudu. Pemberian saponin dapat meningkatkan permeabilitas dinding sel pada usus dan meningkatkan penyerapan zat makanan, sehingga nilai konversi ransum yang dihasilkan lebih baik (Johnson, et al., 1986; Onning et al., 1996). Pada kadar rendah saponin dapat meningkatkan transportasi zat nutrisi antar sel, tetapi pada kadar yang tinggi $10 \mathrm{~g} / \mathrm{kg}$ sudah terjadi gangguan sel. Menurut Sen et al., 1998 saponin pada kadar $0,25 \%$ dapat menurunkan populasi $E$. coli lebih dari 25\%. Bestari, et al. (2005) melaporkan bahwa konversi ransum yang mendapat ransum kontrol $(3,12)$ dan $5 \%$ tepung daun mengkudu direndam air panas $(2,91)$ memiliki nilai konversi jauh lebih tinggi dibandingkan hasil penelitian ini, yakni yang mendapat ransum kontrol $(1,85)$ dan $3 \%$ tepung daun mengkudu $(1,77)$. Perbedaan ini menunjukkan bahwa tepung daun mengkudu sebesar 3\% dapat dijadikan sebagai bahan pakan alternatif untuk menggantikan jagung dalam ransum, karena menghasilkan nilai konversi ransum yang sama dengan ransum kontrol dan komersil. Sedangkan level 1-2\% tepung daun mengkudu dapat memperbaiki efisiensi penggunaan ransum sebesar 7,57\% dan 9,2\% jika dibandingkan dengan ransum kontrol. Nilai konversi ransum merupakan suatu ukuran untuk menilai efisiensi dalam penggunaan ransum, semakin rendah konversi ransum maka akan semakin efisien karena semakin sedikit jumlah ransum yang dibutuhkan untuk menghasilkan pertambahan bobot badan dalam jangka waktu tertentu (Lacy dan Vest, 2004).

\section{Mortalitas}

Persentase mortalitas selama penelitian tidak menunjukkan perbedaan yang nyata $(P>0,05)$ terhadap mortalitas ayam broiler (Tabel 4). Mortalitas hanya terjadi 1 ekor pada ayam yang mendapat ransum kontrol.

Tabel 4. Pengaruh Substitusi Tepung Daun Mengkudu terhadap Mortalitas Ayam Broiler

\begin{tabular}{cl} 
Perlakuan & Mortalitas (\%) \\
\hline R0 & $0,78 \pm 1,56$ \\
R1 & 0 \\
R2 & 0 \\
R3 & 0 \\
R4 & 0 \\
\hline
\end{tabular}

Mortalitas terjadi hanya pada perlakuan kontrol yaitu sebesar 0,78\% (1ekor), dimana pada perlakuan tersebut ransum hanya diberi penambahan feed additive alami. Scanes, et.al. (2004) 
menyatakan bahwa tingkat mortalitas ayam broiler pada manajemen pemeliharaan yang baik dapat ditoleransi hingga 3\%. Angka mortalitas tidak terjadi pada ransum yang menggunakan tepung daun mengkudu dan ransum komersil. Pada ransum yang menggunakan tepung daun mengkudu, hal ini dapat disebabkan karena daun mengkudu mengandungan $\beta$-karoten, Fe, Zn, steroid dan senyawa antrakuinon (damnakantal) yang berfungsi sebagai antiseptik, antibakteri, dan antikanker sehingga daya tahan tubuh ayam dapat meningkat (Wardiny, 2006, Apriyantono \& Farid, 2002). Pada ransum komersil sudah mengandung antibiotik Zinc Bacitracin yang dapat mencegah penyakit, terutama dalam saluran pencernaan dan menghambat pertumbuhan mikroorganisame yang menghasilkan amonia dalam jumlah besar (Leeson \& Summers, 2001).

\section{Persentase Karkas}

Data persentase karkas ayam jantan dan betina disajikan dalam Tabel 5. Disini terlihat bahwa persentase karkas baik pada ayam jantan maupun ayam betina tidak menunjukkan hasil yang berbeda nyata $(P>0,05)$.

Tabel 5. Pengaruh substitusi Tepung Daun Mengkudu (TDM) terhadap karkas ayam broiler

\begin{tabular}{|c|c|c|}
\hline \multirow{2}{*}{ Perlakuan } & \multicolumn{2}{|c|}{ Karkas (\%) } \\
\hline & Jantan & Betina \\
\hline R0 & $68,62 \pm 3,87$ & $66,44 \pm 5,90$ \\
\hline R1 & $69,27 \pm 1,43$ & $68,41 \pm 0,34$ \\
\hline $\mathrm{R} 2$ & $68,53 \pm 0,01$ & $67,71 \pm 1,36$ \\
\hline R3 & $67,31 \pm 3,80$ & $67,19 \pm 0,23$ \\
\hline R4 & $68,54 \pm 1,18$ & $65,90 \pm 6,46$ \\
\hline
\end{tabular}

Karkas adalah tubuh ayam tanpa bulu, darah, kepala, leher, organ dalam dan shank. Rataan persentase karkas dapat dilihat pada Tabel 5, yaitu untuk ayam broiler jantan berkisar antara 67,31 $69,62 \%$ dan ayam broiler betina berkisar antar 65,90-68,41\% dari bobot hidup. Hasil ini lebih tinggi dari hasil penelitian Bestari, et al. (2005) yang melaporkan bahwa persentase karkas ayam broiler yang diberi $(5-15) \%$ tepung daun mengkudu yang direndam dalam air panas antara $(61,09-66,35)$ $\%$.

\section{Persentase Lemak Abdomen}

Pada hasil penelitian ini terjadi penurunan persentase lemak abdomen pada ransum ayam broiler yang mengandung tepung daun mengkudu jika dibandingkan dengan ransum kontrol. Wijayakusuma, et.al. (1996) menyatakan bahwa daun mengkudu mengandung senyawa antrakuinon dan terpenoid yang dapat merangsang produksi dan sekresi cairan empedu serta sekresi lipase pankreas ke dalam duodenum untuk penyerapan lemak serta ekskresi kolesterol melalaui feses. Aayam yang mendapat perlakuan tepung daun mengkudu, ekskresi kolesterol dalam fesesnya akan meningkat sehingga persentase lemak abdomen cenderung menurun. Selain itu bahan herbal pada umumnya mengandung serat kasar yang tinggi, berfungsi melarutkan lemak dalam tubuh ayam 
sehingga persentase lemak abdomen yang dihasilkan lebih rendah jika dibandingkan dengan ransum kontrol (Bintang, et al, 2007).

Persentase lemak abdomen pada ayam jantan dan betina disajikan dalam Tabel 6 , terlihat bahwa pemberian tepung daun mengkudu tidak nyata $(P>0,05)$ menyebabkan perubahan terhadap persentase lemak abdomen ayam broiler.

Tabel 6. Pengaruh Substitusi Tepung Daun Mengkudu (TDM) terhadap Lemak Abdomen Ayam Broiler

\begin{tabular}{|c|c|c|}
\hline \multirow{2}{*}{ Perlakuan } & \multicolumn{2}{|c|}{ Lemak Abdomen } \\
\hline & Jantan & Betina \\
\hline R0 & $2,32 \pm 0,14$ & $2,49 \pm 0,32$ \\
\hline R1 & $1,88 \pm 0,24$ & $2,30 \pm 0,95$ \\
\hline $\mathrm{R} 2$ & $1,76 \pm 0,96$ & $2,17 \pm 0,56$ \\
\hline R3 & $1,86 \pm 0,57$ & $2,44 \pm 0,27$ \\
\hline $\mathrm{R} 4$ & $1,64 \pm 0,10$ & $1,67 \pm 0,16$ \\
\hline
\end{tabular}

\section{KESIMPULAN}

Tepung daun mengkudu mempunyai potensi untuk mensubstitusi jagung dalam ransum ayam broiler sebanyak 1-2\%. Suplementasi tepung daun mengkudu dalam ransum meningkatkan efisiensi pakan, pertambahan bobot badan dan menurunkan mortalitas. Perbaikan konversi ransum sebanyak 7,57\% (R1) dan 9,2\% (R2) lebih efisien dibandingkan kontrol.

Disarankan mengkaji lebih rinci penggunaan campuran tepung daun mengkudu dan buah mengkudu dalam ransum ayam broiler, terutama evaluasi kandungan asam amino dan zat aktif yang terdapat pada mengkudu.

\section{REFERENSI}

Aalbersberg, W.G.L., Husein, S., \& Wirian, A.S. (1993). Journal of Herbs, Spices and Medicinal Plant. 2(1):51-54.

Apriyantono, A., \& Farid, S.L. (2002). Mengkudu (Morinda citrifolia): Efek farmakologis dan teknologi pengolahannya. Saresehan Temu Saran Pengembangan Obat Tradisional Indonesia, Bogor.

Bangun, A.P., \& Sarwono, B. (2002). Sehat dengan ramuan tradisional, khasiat dan manfaat mengkudu. Jakarta: Agromedia Pustaka.

Bestari, J., A. Parakkasi \& Akil, S. (2005). Pengaruh pemberian tepung daun mengkudu yang direndam air panas terhadap penampilan ayam broiler. Bogor: Prosiding Seminar Nasional Teknologi Peternakan dan Veteriner. HIm.703-713.

Bintang, I.A.K., Sinurat, A.P., \& Purwadaria, T. (2007). Penambahan ampas mengkudu sebagai senyawa bioaktif terhadap performans ayam broiler. Jurnal IVT, 12(1), 1-5.

Darusman, L.K. (2002). Mengkudu (Morinda citrifolia): Kandungan bahan aktif dan efek farmakologisnya. Lamongan: Makalah disampaikan pada Pertemuan Koordinasi dalam Rangka Pengembangan Agribisnis Tanam Obat, 25-26 September 2002. 
Johnson, L.T., Gee, J.M., Price, K., Curl, C. \& Fenwick, G.R. (1986). Influence of saponin on gut permeability and active native transpot in vitro. Jurnal Nut. 116:2270-2277.

Lacy \& Vest, L.R. (2004). Improving feed conversion in broiler: A guide for grower. Diambil 23 Maret 2010, dari http://www.ces.uga.edu/pubed.c:793-w.html.

Leeson,S \& Summers, J.D. (2001). Nutrition of the Chicken. (4 $4^{\text {th }}$ Ed). Ontarion: University Bools, Guelph.

Onning, G., Wang, Q., Westrom, B.R., Asp, N.G., \&Karlsson, B.W. (1996). Influence of oat saponin on intestinal permeability in vitro and in vivo in the rat. Jurnal Nutr, 76, 141-151.

Piliang,W.G. (2004). Nutrisi Vitamin Vol. I. Bogor: Pusat Antar Universitas Ilmu Hayati, Institut Pertanian Bogor.

Sangadji, I., Wardiny, T.M., Bestari, J., Allaily, F.O., Meryana, N., \& Parakkasi, A. (2005). Pemberian tepung daun mengkudu yang telah diproses terhadap penampilan ayam broiler. Jurnal IImiah IMPASJA Vol. I No.2. Bogor: Ikatan Mahasiswa Pascasarjana Jambi.

Scanes.C.G., Brant, G., \& Ensminger, M..E.(2004). Poultry Science. (4th Ed). Upper Saddler River, New Jersey: Pearson Education, Inc.

Sen, S., Makkar, H.P.S., MuetzeL, S., \& Becker, K.(1998). Effect of quillaja saponaria saponins and yuca schidigera plant on growth of Escherichia coli. Lett.Appl. MicrobioL, 27: 35-38.

Steel, R.G.D. \&Torrie, J.H. (1993). Prinsip dan prosedur statistika-suatu pendekatan biometrik. Edisi Kedua. Terjemahan: B.Sumantri. Jakarta: PT.Gramedia Pustaka Utama.

Waha, M.G. (2001). Sehat dengan Mengkudu. Jakarta: MSF Group.

Wardiny, T.M. (2006). Kandungan kolesterol dan vitamin A telur ayam yang diberi Mengkudu (Morinda citrifolia) dalam ransum ayam ras petelur. Tesis yang tidak dipublikasikan. Fakultas Pasca Sarjana IPB, Bogor.

Widodo, W. (2010). Ketahanan pakan unggas di tengah krisis pangan. Diambil 16 Pebruari 2010, dari http://cari.pdf.com/download/index.php?name=pakan unggas\&file= wahyuwidodo. staff. umm.ac.id/files/2. 